\title{
The Performance Evaluation of Family Education Working Group in Education Office
}

\section{Imam Suseno*}

Postgraduate Lecturer, Indraprasta PGRI Jakarta University

\section{A R T I C L E I N F 0}

Article history:

Received February

2020

Received in revised

Form 01 March 2020

Accepted 18 April 2020

Available online 30 May

2020

Keywords:

Family Education,

Working Group, Office of

Education

\begin{abstract}
A B S T R A C T
This study aimed at evaluating the performance of the Family Education Working Group of Education Office in Indonesia to oversee the implementation of the family education program. The research method applied a program evaluation through an analysis of policy stage formulation to the implementation of programs specified in government policy. Using primary data, which was collected by researchers through several instruments, namely: (1) filling sheet in the form of inventory checklist, (2) in-depth interviews, and (3) documentation analysis. The results of data analysis showed that the performance of the family education working group showed a positive results, as seen in the results of mentoring in the education unit more than half of the education units including family education program in the school program and class activities agenda.
\end{abstract}

\section{Introduction}

The education as an effort to educate the nation's life is a responsibility of all parties. Philosophically, educating the first and foremost child is the task of the family since it is a small environment for children to begin knowing everything for the first time.

The best education is certainly presented in a well planning, processing in detail with the implementation of the best learning strategies, fulfilling an adequate infrastructure, and considering students' knowledge and skills needs, and increasing community participation. The increase of community participation is needed when the government's ability is still limited in managing national education. In addition, the role and participation of the community are expected to eliminate the attitude of "all taken for granted" which it belongs to all government obligation (central) and the community obligation is to accept it. The community does not care and they become irresponsible. Spontaneous participation of the community will foster creativity and increase productivity as well as increase the responsibility for the development and its results (Suseno, 2018: 782).

Family involvement, especially students' parents in the education unit, has a big role to succeed in the children's education. The results showed a positive relationship between parents' participation and children's learning achievement and to optimize other aspects of children's development. Parents' involvement in children's education is considered a multidimensional construction consisting of parental behavior and beliefs about children's education, both at home and at school (Englund et al, 2004, in Riany, 2018). Whereas Latunde (2017: 9) states that Parents' involvement can be seen from how the impact of Parents' involvement on the policies for supporting the activities at school, and how parental communication patterns such as providing an idea or suggestion for children how to behave in the family and school. 
According to Hornby (2011: 1) Parents' involvement is defined as a participation of parents in the processes and experiences children's education. Basically, the involvement of parents at home environment can be seen as how parents communicate, listen to stories that have been experienced by children at school, parents can also accompany their children in doing school assignments. Dempsey (2005: 23) states that Parents' involvement, in general, can be described as parent investment in children's education from various sources that can be assessed from encouragement, modeling, reinforcement, and instruction.

Diandha (2015: 67) mentions several factors that influence Parents' involvement including individual parent factors, from various family and personal problems that will influence Parents' involvement in their children's education such as: (1) parents' beliefs about the importance of their involvement in children's education, (2) parental perceptions of involvement invitation, (3) parental life context. Especially on the parents' perception, it depends on the attitude shown by the teacher

Due to the important role of parents in educating children related to the children's learning activities, socioeconomic status about learning motivation and student achievement has an indirect effect (Rahayu, 2011: 73). Clark (in Mariyana et al, 2010) states that the involvement of parents and the community in the children's education at school is to foster students' confidence and enhance a good relationship between parents and children, besides it increases the collaboration between school and community and reduces the conflicts at school. The form of Parents' involvement is more complex than what parents have already known and applied at school. An educational institution that understands the importance of Parents' involvement in the children's education at school, will always try to provide various alternative Parents' involvement activities for them to follow by considering their conditions and accommodating the parents' need at the school (Epstein, 2002, in Diadha, 2015: 64).

Government through formal rules, namely Minister of Education and Culture Regulation No. 30 of 2017 regulates how the form of family involvement in the education administration. Then in the organization structure of the Ministry of Education and Culture, there is a Directorate of Education Development which has an objective to strengthen the partnerships between education unit, family, and community (Three Main Education) in building educational ecosystems that foster the character and culture of students' achievement.

As a strategy to run a family education program effectively, achieving goals, and be sustainable, a family education working group was formed in Education Office at the Province / Regency / City. As legal guide for the formation of the working group of Education Office at Province / Regency / City, the Regulation of the General Director of Early Childhood Education and Community Education No.130 of 2017 concerning the Establishment of Working Group at Province Education Office and Regency / City Education Office.

The family education working group as a public sector organization in the regional government is demanded to have performance-oriented towards community' interest, and encourage to be responsive to its environmental guidance by providing the best services in a transparent and quality manner. Mardiasmo (in Wahyuni \& Rosmida, 2017: 12) argues that it requires a very strong desire to encourage government organizations to be more efficient and effective by eliminating the stereotypes that have been embedded in government agencies, namely a hotbed of inefficiency, waste, sources of fund leakage, and institutions that loss becomes the main factor of adoption on the performance measurement system in a government agency. Based on the opinion, it is necessary to evaluate the performance of Family Education Working Group.

Evaluation as research is used to collect, analyze, and present the useful information about the object of evaluation, assess it by comparing it with the evaluation indicator, and the results are used to decide the object of evaluation (Wirawan, 2011: 7). The evaluation activities consist of gathering information to decide about the implemented program (Mardapi, 2009: 231). According to Valadez \& Bamberger (in Mardapi, 2009: 12) states that the objective of the evaluation activities is to assess the suitability of program plan with its implementation methods to achieve goals, assess the program results, both expected and unexpected results, and assess the influenced factors toward the program success.

The performance of the measurement system is expected to increase transparency, accountability, and efficiency as well as the effectiveness of public organizations. The public institutions are expected to have good performance, which is indicated by the institution's stewardship and accountability towards their managed public resources (Wahyuni \& Rosmida, 2017: 12). An effort to achieve organization objectives are strongly influenced by the overall environment which includes internal and external aspects of the organization, Steers (1980) explains that internal influences are creating milieu cultures and social to take place towards the organization objectives or climate, and a change description that occurs in internal organizations like a change of organization objective, and the influence of the external environment that occurs outside the organization, for example, a change of social structure, change of an 
economic condition, political situations, or the increasing amount of demands directed at the organization of society, institutions or agencies outside the organization.

Furthermore, Steers (1980) states that in order to achieve the success of organization objective, it cannot be separated from the environmental influences, namely: 1) the predictability of environmental conditions, 2) the perception accuracy of environmental conditions, and 3) the understanding of rationality and organization action. The family education working group is an organization that is able to accommodate the aspirations of education office and outside of education office (partners) that have a common interest on the success of the national education goals. Keban (2014:227) states that an effective organization can be said due to its organization's goals or values, as set in its vision, are achieved. These values are values that have been mutually agreed between the stakeholders and concerned organization

Based on the background above, it is important to conduct the performance evaluation activities of the family education working group of Education Office at Province / Regency / City in Indonesia, to assess how effective, the benefits, and its performance to take a part in overseeing the implementation of family education programs in the target area.

\section{Methods}

This study was an evaluation type of family education working group's performance of Education Office at Province / Regency / City in Indonesia. The design of performance evaluation started from the analysis stage of policy formulation to the implementation of a specified program in government policy. Performance evaluation was a method and evaluation process and implementation of a person or group of people tasks or work units in an organization based on the performance standard or objective. Therefore, the use of the qualitative method was intended to: 1) examine the selected issues possibly in-depth and in detail, 2) obtain the detailed and deep data from respondents with a limited amount, 3) explain the situation, events, interactions, and behavior of the observed subjects, (Patton, 2002: 20).

The population of this evaluation was the family education working group spread across 274 Education Office at Province / Regency / City in Indonesia. The sample of the study was 176 working groups which were obtained by using a simple random sampling technique.

The obtained data belonged to primary data that were collected directly by the researcher through several instruments, namely: (1) Inventory checklist of activities that had been conducted by family education working group at Province/ Regency/City, (2) In-depth interviews to the family education working group that was collected in an activity organized by Directorate of Education Development, (3) Documentation analysis was the performance report of family education working group at Province /Regency/City in 2019. Working group activity report and brief contents of profile: organization, planning, implementation, supervision on the implementation of family involvement program in the education unit which was the result of assistance and guidance, as well as working group partnerships with relevant institutions in the intervention of the family education program in the education unit.

The success of family education working Group indicator performance as outlined in the Technical Guidelines for the Establishment of the Family Education Working Group: (1) There is a coordination between family education working group and relevant agencies/institutions regarding the implementation of family education in each semester of the school year; (2) The existence of a work guidance and assistance program in the implementation of family education programs to education units every semester of the school year; (3) There is guidance and assistance provided by the family education working group to education units that had received Technical Guidance on the implementation of family education; (4) There is an evaluation result of family education program conducted by the family education working group; (5) There is a report of family education working group activity on the implementation of family education programs in the education unit.

\section{Result And Discussion}

The performance evaluation of family education working group is intended to assess the achievement of public organizations in the education office in achieving the objectives. As Wirawan (2009: 11) explains that performance evaluation is an appraisal process of officials who conducts an appraiser to collect information about the performance assessment, an employee assessed by the appraiser that is formally documented to assess valuation performance by comparing it with its performance standards periodically to assist in taking decision of human resource management. The result of the performance evaluation determines the achievement of the organization in achieving the goals.

Performance is a record of the effects that is resulted in a job function or activity during a certain period related to organization goals. To achieve a professional performance, it is necessary to develop things, such as volunteerism, personal self-development, the development of mutually beneficial 
cooperation, and full participation. Performance is used to monitor the productivity of human resources work both production, services, and care (Baharun, 2016: 246-247).

Family Education Working Group was formed as an effort by Directorate of Education Development to implement the policy in fostering family education field to strengthen partnerships among family, education unit, and community as tri center of education to build a family education ecosystem that was able to foster the character and culture of learners' literacy, thus, based on the Regulation of General Director of Early Childhood Education and Community Education No.130 of 2017 concerning the Formation of Education Office Working Groups at Province and Education Office at Regency/City.

However, the performance indicators are aspects that become a measurement in assessing performance. Performance measurement is needed because it is useful for all parties. The performance measurements of family education working group are listed in the Regulation of the General Director of Early Childhood Education and Community Education No. 130 of 2017, concerning the Technical Guidelines for the Establishment of Family Involvement Working Groups of Education Office at Province and Education Office at Regency/City. The success indicators of family education working group performance are composed of five points. The results of the performance analysis of working groups are divided into five as follows:

\section{A. Indicator 1. There is a coordination between family education working group and related institutions regarding the implementation of family education;}

The coordination of family education working groups with various relevant agencies concerning the implementation of family education including representatives from: School Principals Group Discussion, Social Office, Health Office, Regional Revenue Agency, Police, KPAI, HIMPAUDI, IGTKI, BNN, etc. Coordination meetings are held in focus group discussion forums to provide an input on social conditions and social phenomena that becomes the input for the working group to be able to behave towards various social phenomena that can damage family and students.

One of the reasons family education working group formation is to increase the effective implementation coordination of family education with various agencies/institutions /organizations. Family education working group has a task and function to assist Education Office at Province/Regency/City in fostering and implementing family education programs. It was formed through Education Office decree at Province/Regency/City whose membership involved the representatives/elements from across sectors in the education office, regional work units or related agencies, and family education institutions/organizations/activists.

Through a cooperation with various cross-agency agencies and other institutions in order to have the same view and well organized schedule in socialization activities and strengthen the parents and students capacity. The results of the coordination meeting also obtain some information that each office and agency also have an agenda to provide a various information for school, parents, and students. The socialization activities as a form of preventive efforts from various negative actions that can damage Indonesian nation in terms of social, moral, and character. Preventive efforts are to prevent: the brawls between students, bullying, drugs, promiscuity, HIV-AIDS, addicted girl, criminal human trafficking, and so on.

\section{B. Indicator 2. The existence of a guidance and assistance family education work program in education units every semester of the school year.}

The purpose of Family Education Working Group establishment is to: (1) Increase an effective implementation coordination of family education with various related agencies/ institutions/organizations; (2) Increase the capacity of school supervisors, non-formal education inspectors, family education trainers/facilitators in the framework of guiding, assisting, and supervising the implementation of family education programs in family, education units and community; (3) Increase the effective guidance and assistance in the implementation of family/parent involvement in education units related to their authority.

The family education working group membership consists of a coordinator (secretary of the education office or other appointed official), a secretary, and several members (as needed) consisting of elements, namely: Heads Divisions of Education Office, Early Childhood and Community Education, related offices or agencies, supervisors/observers, and trainers/facilitators/family education activists, and other relevant elements.

Thus, the work program of fostering and assisting the implementation of family education programs in education units conducted by family education working group has been formulated in a joint decision covering activities as follows:

1) Family education socialization in Early Childhood Education, Primary School, and Junior High School. 
2) Members/supervisors will oversee the implementation of family education in the target education unit and disseminate it to other schools

3) Providing an assistance to formal and non-formal education units

4) The dissemination of assistance instruments to the education unit

5) Making a circular for the implementation of the First Day of School Entry

6) Compiling a needs analysis, determining the date of mentoring activities in family education program, family education working group of FGD activities in the education unit.

7) The involvement of supervisors in the working group: the teacher is more active to compile a list of mobile phone of students' parents'.

8) Conducting family education in education units starting from Kindergarten, Elementary School, and Middle School

9) Increasing the capacity of family education at Province working groups to collaborate and work together with regency working groups and education units/institutions.

C. Indicator 3. There is a guidance and assistance provided by the family education working group to education units that have received Technical Guidance on the implementation of family education.

The existence family education working group is expected to assist Education Office at Province and/or Regency/ to improve the effectiveness and sustainability of family education programs. For this reason, empowerment and capacity building of working group are needed. The model of fostering family education by family education working group can be seen in the following figure:

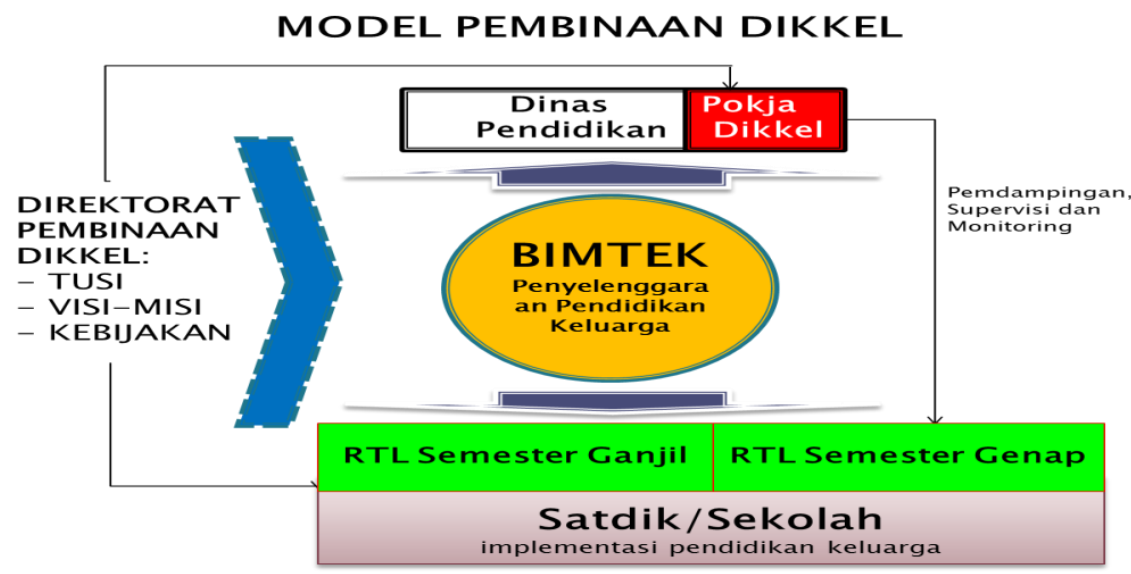

Figure 1. The Model of Fostering Education Family Program

Note:

Pokkel Dikkel: Family Education Working Group

Bimtek: Technical Guidance of Organizing Family Education

RTL: Follow-up Plan

Education unit: Education Unit

The guidance of program implementation in education units is conducted by working group through supervision of program implementation in education units. Supervision programs that are conducted by overseers or supervisors are integrated with the task program as overseers or supervisors in education units using provided instruments.

To get an optimal results in overcoming various problems in the education unit, the working group also provides an assistance in the education unit by using facilitators or family education practitioners. The assistance program of family working is expected to provide an input for optimizing family involvement in education units.

The assistance of education units is used to ensure the implementation of family education programs in education units. Based on the data that has been entered, it shows that $11 \%$ of family education working groups have not provided assistance, 58\% have conducted mentoring once in 2018, and $32 \%$ have conducted twice mentoring in education units. 


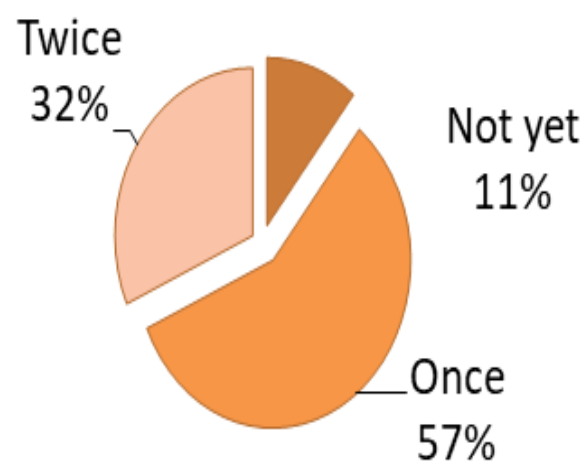

Figure 2. Education Unit Assistance

The implementation purpose of family education assistance in the education unit is to ascertain whether: (1) There is a problem in the education unit that has received ecosystem assistance and partnerships in implementing family education programs, (2) Family education programs are still conducted by education units that have received ecosystem assistance and partnerships in 2015, 2016, 2017, and 2018.

\section{Indicator 4. The existence of a performance evaluation result of family education programs by the family education working group.}

Some positive responses toward the implementation of the family education program from all respondents argued that family education programs and family education working groups of Education Office at Province and Regency/City were urgently needed. Various activities of the family education program as an endeavor to fix the students' affective and conative aspects in the education unit and the parents' involvement in the education administration. In brief, the benefits of family education working group of education office can be formulated as follows:

1) Being able to ease the duty Education Office in terms of improving character education;

2) Strengthening a coordination between the Education Office and related Agencies as partners;

3) Interrelated to support this program, schools can make a partner with parents and the community;

4) Faster socializing and implementing family education in the region.

Besides, the benefits of family education working group in monitoring the implementation of family education programs for the Education Unit can be described as follows:

1) Parenting results, children are close to parents;

2) There is awareness from parents and community to be better in giving attention to the sons, daughters, and children of the nation;

3) Parents' participation in schools is increasing;

4) There is a collaboration and communication among schools, parents, and the community;

5) Increasing the role and concern of parents and community to succeed in the school programs;

6) Parents and the community increasingly have their awareness and responsibility of their children's success.

Schools through the working groups can get reinforcement and assistance regarding the implementation of family education programs in education units.

The implementation of inspirational classes by presenting various speakers coming from students' parents, community leaders, and other professions who are able to provide an inspiration for students. The implementation of inspirational classes is not expected to interfere the teaching and learning activities in class, but it can provide an illustration or can reinforce the way students obtain their desired dreams. 


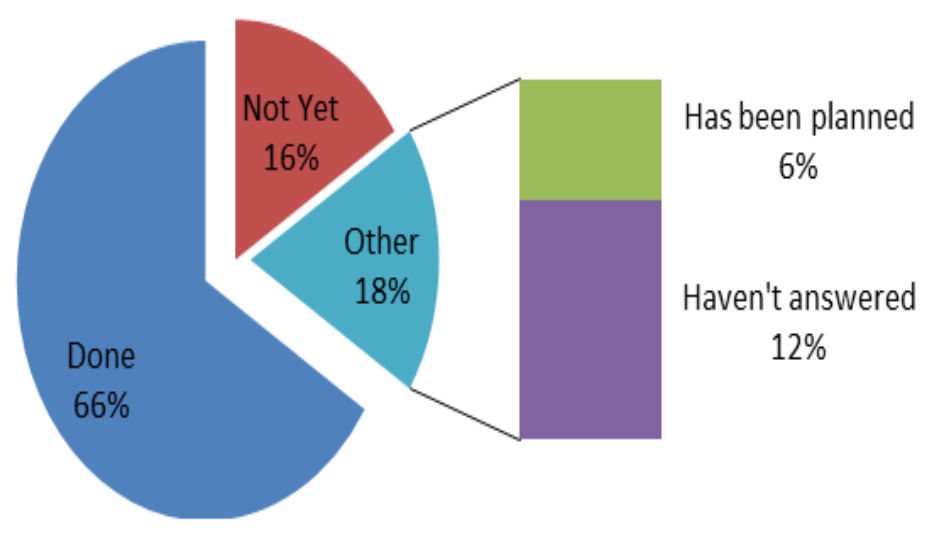

Figure 3. Parent involvement in co-curricular and extracurricular activities

The results of working group assistance in education unit showed that $66 \%$ of the education unit had involved students' parent in year-end class activities. As an evaluation form of family education implementation or parent involvement in the education unit, the education unit should conduct routine evaluation activities in order to ensure the program and quality implementation of family education program.

\section{E. Indicator 5. There is an activity report of family education working group on the implementation of family education programs in the education unit}

Family Education Working Group has a task for conducting an assistance, coaching, and monitoring, and evaluating the implementation of family education in the education unit. Based on the obtained data, it shows the results of technical guidance and or socialization by supervisors and inspectors, the education unit has an agenda or family education program by involving parents/guardians in the education administration units around 79\%, who do not have an agenda around $8 \%$ and had planned around $7 \%$.

Table 1. Results of Family Education Working Group Assistance in Education Unit

\begin{tabular}{|c|c|c|c|c|c|}
\hline No & Activities & Available & Unavailable & Planned & $\begin{array}{c}\text { Do not } \\
\text { Respond }\end{array}$ \\
\hline 1 & $\begin{array}{l}\text { The education unit schedule family } \\
\text { involvement program }\end{array}$ & $79 \%$ & $8 \%$ & $7 \%$ & $6 \%$ \\
\hline 2 & $\begin{array}{l}\text { The education unit include in the } \\
\text { school program, academic calendar, } \\
\text { and class agenda }\end{array}$ & $76 \%$ & $10 \%$ & $6 \%$ & $8 \%$ \\
\hline 3 & $\begin{array}{l}\text { The education unit Education unit } \\
\text { identify the potential of students' } \\
\text { parents as school partners }\end{array}$ & $72 \%$ & $16 \%$ & $5 \%$ & $7 \%$ \\
\hline 4 & $\begin{array}{l}\text { The education unit identify the } \\
\text { potential of community as school } \\
\text { partners. }\end{array}$ & $65 \%$ & $21 \%$ & $4 \%$ & $10 \%$ \\
\hline 5 & $\begin{array}{l}\text { The education unit be a partner with } \\
\text { other institutions/institutions }\end{array}$ & $76 \%$ & $8 \%$ & $3 \%$ & $13 \%$ \\
\hline 6 & $\begin{array}{l}\text { The education unit analyze the need } \\
\text { for forming positive students' } \\
\text { characters }\end{array}$ & $71 \%$ & $12 \%$ & $5 \%$ & $12 \%$ \\
\hline 7 & $\begin{array}{l}\text { The clarity of organization in family } \\
\text { education implementation of } \\
\text { education unit }\end{array}$ & $66 \%$ & $16 \%$ & $5 \%$ & $13 \%$ \\
\hline
\end{tabular}

The Table above shows that only $79 \%$ of education units are assisted and fostered by the Family Education Working Group that has an agenda for involving families in sharing education implementation in the education unit. 
There are ten forms of parent/guardian involvement that are expected to be included in the school program, academic calendar, and class agenda. The inclusion involvement in various programs and agendas shows that the education unit really has a complete family education plan. From the obtained sample, $76 \%$ of the education unit has included family education program in the school program, academic calendar, and class agenda in the education unit.

\section{Conclussion}

Various positive responses toward the substance of the family education program from all respondents indicate that family education programs and family education working groups of Education Office at Province and Regency/City are urgently needed. Various activities of the family education program as an endeavor to fix the students' affective and conative aspects in the education unit and parents' involvement in the education administration.

The performance of family education working group shows a positive results as seen in the results of mentoring in the education unit more than half of the education units have included the family education program in school program and class activities agenda.

Family education working program views the implementation of the family education program as Regulation of Education and Culture Minister No.30 of 2017 is not yet intact, but rather tends to be partial;

The separation or boundaries of fostered area between Education Office at Province/Regency/City and education unit becomes an obstacle in reaching all targets, for example, High School/Vocational School is fostered by the Province Office but the location of schools and students is in the Regency/city. So, responsive events that occur in high school/vocational school are slow.

Family education working group does not have education unit data that has received Technical Guidance and or Complete Family Education Program Socialization.

\section{Reference}

Dempsey, Hoover. 2005. The Social Context of Parents' involvement: a path to enhanced achievement. Nashville: Vanderbilt University.

Diadha, Rahminur. 2015. Keterlibatan Orang tua dalam pendidikan anak usia dini di taman kanak-kanak. Edusentris, Jurnal ilmu Pendidikan dan Pengajaran, Vol. 2 No. 1, Maret 2015

Hornby, Garry. 2011. Parents' involvement in Childhood Education Building Effective School-Family Partnerships, New York: Springer.

Keban, Yeremias T. 2014. Enam Dimensi Strategis Administrasi Publik Konsep, Teori dan Isu. Yogyakarta: Gava Media.

Latunde, Yvette C. 2017. Research in Parents' involvement: Methods and Strategies for Education and Psychology. California, USA: Azusa Pacific University.

Mardapi, Djemari. 2009. Evaluasi Penerapan Ujian Akhir Sekolah Dasar Berbasis Standar Nasional. Jurnal Penelitian dan Evaluasi Pendidikan Tahun 13, Nomor 2, 2009.

Mariyana, Rita., Nugraha, Ali,. \& Rachmawati, Yeni. 2010. Pengelolaan Lingkungan Belajar, Jakarta: Kencana Prenada Media.

Patton, Michael Quinn. 2002. Qualitative Research and Evaluation Methods. California: Sage Publication.

Peraturan Menteri Pendidikan dan Kebudayaan Republik Indonesia Nomor 30 Tahun 2017 tentang Pelibatan Keluarga pada Penyelenggaraan Pendidikan.

Peraturan Direktur Jenderal Pendidikan Anak Usia Dini dan Pendidikan Masyarakat Nomor. 127 Tahun 2017, tentang Petunjuk Teknis Pelibatan Keluarga pada Satuan Pendidikan. 
Peraturan Direktur Jenderal Pendidikan Anak Usia Dini dan Pendidikan Masyarakat Nomor. 130 Tahun 2017, tentang Petunjuk Teknis Pembentukan Kelompok Kerja (Pokja) Pelibatan Keluarga pada Dinas Pendidikan Provinsi dan Dinas Pendidikan Kabupaten/Kota.

Riany, Yulia Eva. 2018. Orang Tua Terlibat Prestasi Anak Meningkat. https://sahabatkeluarga.kemdikbud.go.id/laman/index.php?r=tpost/xview\&id=249900009 (Dilihat April 2019).

Rahayu, Wening Patmi. 2011. Analisis Intensitas Pendidikan Oleh Orang Tua dalam kegiatan belajar anak, status sosial ekonomi orang tua terhadap motivasi belajar dan prestasi belajar siswa. Jurnal Pendidikan dan Pembelajaran, Vol.18 Nomor 1, April 2011.

Suseno, Imam. 2018. Evaluasi Program Pendidikan Keluarga Pada Satuan Pendidikan. Seminar Nasional dan Diskusi Panel Multidisiplin Hasil Penelitian dan Pengabdian Kepada Masyarakat, Jakarta 2 Agustus 2018.

Steers, Richard M. 1980. Efektifitas Organisasi, terjemahan Magdalena Jamin. Erlangga: Jakarta.

Thoha, Miftah. 1988. Perilaku Organisasi. Rajawali: Jakarta.

Wahyuni, Endang Sri \& Rosmida. Analisis Pengaruh Budaya organisasi,locus of control terhadap kinerja aparat pemerintah daerah dan kepuasan kerja sebagai variabel Intervening. Jurnal Inovasi dan Bisnis,Vol.5, No.1 Juni 2017.

Wirawan. 2011. Evaluasi Teori, Model, Standar, Aplikasi, dan Profesi. Jakarta: Rajawali Pers.

Wirawan. 2009. Evaluasi Kinerja Sumber Daya Manusia. Jakarta: Salemba Empat. 